\title{
EFFECTS OF CALCINATION TEMPERATURE ON HYDROTHERMALLY SYNTHESIZED TITANIUM DIOXIDE SUBMICRON POWDERS
}

\author{
${ }^{1}$ Büşra BULUT (iD) , 2 Şeyma DUMAN \\ 1,2Bursa Technical University, Engineering and Natural Sciences Faculty, Metallurgical and Materials \\ Engineering Department, Bursa, TURKEY \\ ${ }^{2}$ Bursa Technical University, Central Research Laboratory, Bursa, TURKEY \\ ${ }^{1}$ mbusrabulut@gmail.com, 2 seyma.duman@btu.edu.tr
}

(Geliş/Received: 13.04.2021; Kabul/Accepted in Revised Form: 30.06.2021)

\begin{abstract}
This study examines the synthesis procedure of titanium dioxide $\left(\mathrm{TiO}_{2}\right)$ submicron powders from titanium (IV) isopropoxide initial by combining the hydrothermal method and subsequent calcination. Various calcination temperatures changing from $200{ }^{\circ} \mathrm{C}$ to $800{ }^{\circ} \mathrm{C}$ were applied after hydrothermal synthesis to understand the effects on the crystalline phase, particle size, and morphology of the powders. Following the calcination procedure, the properties of synthesized powders were assessed by using different characterization techniques. According to the results of morphological analysis, the crystalline structure of submicron powders was affected by increasing calcination temperature. Anatase and rutile phases of $\mathrm{TiO}_{2}$ submicron powders displayed unimodal particle size distribution, respectively. Furthermore, the particle sizes of synthesized $\mathrm{TiO}_{2}$ submicron powders decreased by the increasing calcination temperature, while the crystallite sizes increased. The results of phase analysis revealed that $\mathrm{TiO}_{2}$ submicron powders have tetragonal structure anatase and rutile phase. In particular, anatase to rutile phase transformation was carried out at low temperatures.
\end{abstract}

Key Words: Titanium dioxide, Hydrothermal synthesis, Calcination temperature, Crystalline phase

\section{Hidrotermal Olarak Sentezlenen Titanyum Dioksit Mikronaltı Tozları Üzerine Kalsinasyon Sıcaklığının Etkileri}

ÖZ: $\mathrm{Bu}$ çalışma, titanyum dioksit $\left(\mathrm{TiO}_{2}\right)$ mikronaltı tozların titanyum tetraizopropoksit başlangıç malzemesinden, hidrotermal yöntem ve ardından yapılan kalsinasyon ile sentezlenme prosedürünü incelemektedir. Hidrotermal sentez sonrası yapılan kalsinasyon işleminin, $200{ }^{\circ} \mathrm{C}$ 'den $800{ }^{\circ} \mathrm{C}^{\prime}$ ye kadar değişen sıcaklıklarda uygulanması ile, bu sıcaklıkların elde edilen tozların kristal fazı, morfolojisi ve partikül boyutu üzerindeki etkileri araştırılmıştır. Kalsinasyon işlemini takiben, elde edilen tozlar çeşitli karakterizasyon teknikleri kullanılarak incelenmiştir. Morfolojik analiz sonuçlarına göre mikronaltı tozların kristal yapısı artan kalsinasyon sıcaklığından etkilenmiştir. Anataz ve rutil faza sahip $\mathrm{TiO}_{2}$ mikronaltı tozlar, sırasıyla iki modlu ve tek modlu partikül boyut dağılımı göstermişlerdir. Ayrıca, kalsinasyon sıcaklığı arttıkça sentezlenen mikronaltı tozların partikül boyutları azalırken, kristalit boyutları artmıştır. Faz analizi sonuçları, tetragonal yapıda anataz ve rutil faza sahip $\mathrm{TiO}_{2}$ mikronaltı tozları ortaya çıkarmıştır. Özellikle, anatazdan rutil faza dönüşüm düşük sıcaklıklarda gerçekleştirilmiştir.

Anahtar Kelimeler: Titanyum dioksit, Hidrotermal Sentez, Kalsinasyon sıcaklığı, Kristalin faz 


\section{INTRODUCTION}

Over the past decades, submicron-structured $\mathrm{TiO}_{2}$ has been the most widely investigated semiconducting metal oxide owing to peerless chemical and physical properties (Corradi et al., 2005; Tan et al., 2015; Wu et al.,2015). Moreover, it possesses numerous potential application fields including photocatalysis (Pelizzetti and Minero, 1993; Rao and Dube, 1996; Hashimoto et al., 2005), gas sensor (Zheng et al., 2000; Bankstein and Semancik, 2006), pigments (Hird, 1976), photovoltaics and electrochromic (Chen and Mao, 2007) which required for specific crystalline phase, particle size and particle shape (Corradi et al., 2005). The $\mathrm{TiO}_{2}$ has three different crystalline phases as anatase, rutile, and brookite. Each crystalline phases have different bandgaps due to consists of different oriented $\mathrm{TiO}_{6}$ octahedral chains (Tomić et al., 2015; Li et al., 2008). While the most common phase of $\mathrm{TiO}_{2}$, anatase generally used for photocatalytic purposes (Tomić et al., 2015; Manjunath et al., 2018), the rutile phase is used to improve mechanical properties in load-bearing applications (Feng et al., 2015). These crystalline phases of $\mathrm{TiO}_{2}$ can be strongly affected by experimental parameters and the preparation methods.

Recently $\mathrm{TiO}_{2}$ submicron-structures produced by diverse synthesis techniques such as sol-gel route (Bankstein and Semancik, 2006), hydrolysis (Chen et al., 2003), hydrothermal method (Yang et al., 2001; Andersson et al., 2002; Chae et al., 2003; Cano-Casanova et al., 2018), flame synthesis (McCormick et al., 2004), and chemical vapor deposition (Ayllon et al., 1999) using different raw materials. Among them, the hydrothermal method is an effective way to prepare well-crystallized $\mathrm{TiO}_{2}$ submicron particles (Tomić ve diğ., 2015). For instance, Yang et al. studied the synthesis of highly crystallized anatase $\mathrm{TiO}_{2}$ submicron powders by hydrothermal approach from peptized tetraalkylammonium hydroxide sols. Chae et al. demonstrated how to obtain $\mathrm{TiO}_{2}$ submicron particles having a specific particle size and crystallization by controlling the Ti precursor and solvent system during hydrothermal synthesis. Cano-Casanova et al. documented the synthesis of highly crystallized $\mathrm{TiO}_{2}$ submicron powders with small crystal size when the change of $\mathrm{HCl}$ concentration. The original aspect of this study is the study of the recently synthesized $\mathrm{TiO}_{2}$ submicron powders at the lowest temperature for the powder metallurgy applications.

In this paper, $\mathrm{TiO}_{2}$ submicron powders were obtained by the hydrothermal method and subsequent heat treatment. A variety of temperatures $\left(200{ }^{\circ} \mathrm{C}-800{ }^{\circ} \mathrm{C}\right.$ in) were applied to the submicron powders in order to reveal the crystalline formation and calcination temperature relation of $\mathrm{TiO}_{2}$. The characterization of synthesized submicron powders was conducted using by X-ray diffractometer (XRD), a scanning electron microscope coupled with energy dispersive spectroscopy (SEM/EDS), and a particle size distribution analyzer (Nano-PSD). Phase transformation temperatures of anatase to rutile were discussed in detail.

\section{MATERIAL AND METHODS}

\subsection{Raw Materials and Powder Synthesis}

Titanium (IV) isopropoxide (TTIP, $\mathrm{C}_{12} \mathrm{H}_{28} \mathrm{O}_{4} \mathrm{Ti}$, Alfa Aesar ${ }^{\mathrm{TM}}$ ) as the source of $\mathrm{TiO}_{2}$ and urea $\left(\mathrm{CH}_{4} \mathrm{~N}_{2} \mathrm{O}\right.$, Merk $^{\mathrm{TM}}$ ) as the catalyst were used as raw materials. Firstly, $5 \mathrm{~g}$ of urea was added to $200 \mathrm{~mL}$ of purified water under magnetic stirring (Stuart ${ }^{\mathrm{TM}} \mathrm{UC152D}$ ). $50 \mathrm{~mL}$ of TTIP was slowly dripped into solution A and stirred vigorously for one $\mathrm{h}$ to mix homogeneously. Subsequently, the mixture was transferred into 200 $\mathrm{mL}$ Teflon autoclave reactors and kept at $100^{\circ} \mathrm{C}$ for 24 hours in an oven $\left(\right.$ Ecocell $\left.{ }^{\mathrm{TM}}\right)$. After the hydrothermal treatment, autoclaves were taken from the oven left to cool for a while at room temperature. By centrifugally (Hettich ${ }^{\mathrm{TM}}$ Universal 320/320R) separated the solid structure, which partially settled in the bottom of cooled autoclaves from the suspension form. The homogeneous precipitates formed in the reactors were washed several times with acetone and distilled water, respectively. By washing with pure water, it was ensured that waste anionic impurities were removed from the wet powder surface and particle size differences were prevented. The hydrothermally treated powders were dried at $90^{\circ} \mathrm{C}$ for 12 hours. Finally, the powders were calcined using a chamber-type laboratory furnace (Protherm ${ }^{\mathrm{TM}}$ PLF $160 / 7)$. The calcination temperature was applied as $200^{\circ} \mathrm{C}, 300^{\circ} \mathrm{C}, 400^{\circ} \mathrm{C}, 500^{\circ} \mathrm{C}, 700^{\circ} \mathrm{C}$, and $800{ }^{\circ} \mathrm{C}$ for $4 \mathrm{~h}$ 
with a heating of $5{ }^{\circ} \mathrm{C} / \mathrm{min}$ in an air atmosphere. The calcinated powders were designated as T200, T300, T400, T500, T700, and T800, respectively. The experimental details were illustrated in Figure 1.

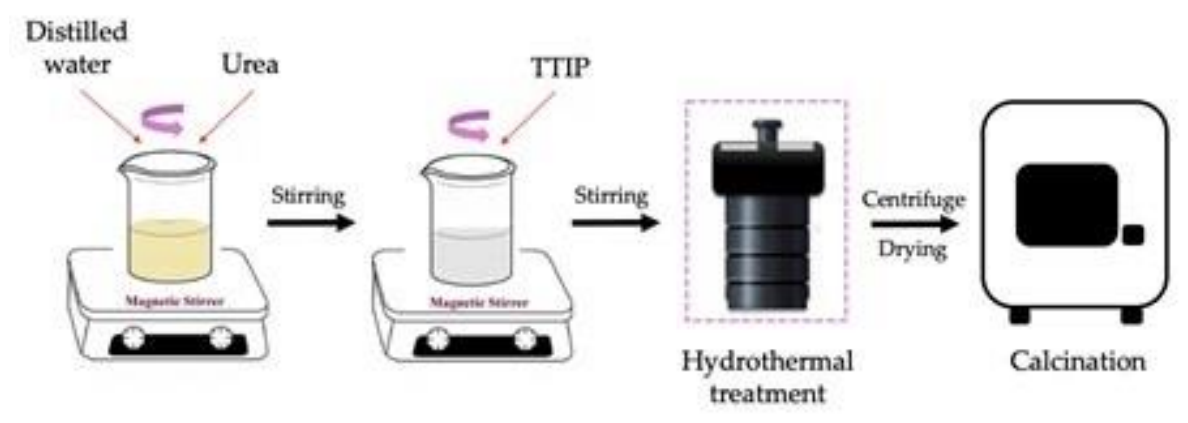

Figure 1. The illustration of experimental set-up.

\subsection{Characterization}

The morphological features of the hydrothermally treated and calcinated submicron powders were investigated by a Carl Zeiss ${ }^{\mathrm{TM}} / \mathrm{Gemini} 300$ scanning electron microscope (SEM) coupled with an energydispersive X-ray spectrometer (EDS). The microscope operated at an accelerating voltage of $20 \mathrm{kV}$. The structural identification of the phases formed was recorded using a Bruker ${ }^{\mathrm{TM}}$ Discovery X-ray diffractometer $(\mathrm{XRD})$ with $\mathrm{CuK} \alpha(0.154 \mathrm{~nm})$ radiation for $2 \theta$ values from $20^{\circ}$ to $80^{\circ}$ with a step size of $5 \% \mathrm{~min}$. The diffractometer operation conditions were $40 \mathrm{kV}$ and $40 \mathrm{~mA}$. The average particle size of the synthesized submicron powders was analyzed using a Malvern ${ }^{\mathrm{TM}}$ Mastersizer 3000 particle size analyzer (PSA).

\section{RESULTS AND DISCUSSIONS}

The morphological differences in $\mathrm{TiO}_{2}$ submicron powders were investigated based on the calcination temperatures. The SEM images in Figure 2 show the $\mathrm{TiO}_{2}$ submicron powders after calcination at different temperatures having irregular clusters with a diameter around $300 \mathrm{~nm}$. Although the SEM images of particles revealed similar morphologies, the aggregation amounts of particles were enhanced with increasing calcination temperatures. This is particularly more clear in the images of the rutile phase of $\mathrm{TiO}_{2}$ submicron powders calcinated at $400{ }^{\circ} \mathrm{C}$ (Figure 2 (c)). Moreover, it was observed that agglomeration could not be prevented in powders synthesized by the hydrothermal method. Our findings are compatible with the outcomes of a study conducted by Ding et al. (2010). In basically, they showed that no control of shape and size on phase-pure rutile submicron powders was available. As in the literature (Ding et al., 2010; Mioduska et a., 2016; Phromma et al., 2020), calcination temperature on the morphological and particle size of $\mathrm{TiO}_{2}$ submicron powders has played a crucial role in this study. The EDS results show the presence of $\mathrm{Ti}$ and $\mathrm{O}$ atoms in the structure and no impurities have been observed. 
Table 1. Physical properties of the synthesized $\mathrm{TiO}_{2}$ submicron powders.

\begin{tabular}{c|ccc}
\hline Sample & $\begin{array}{c}\text { Particle Size } \\
(\mathbf{n m})\end{array}$ & $\begin{array}{c}\text { Specific surface } \\
\text { area }\left(\mathbf{m}^{2} / \mathbf{g}\right)\end{array}$ & $\begin{array}{c}\text { True Density } \\
\left(\mathbf{g} / \mathbf{c m}^{3}\right)\end{array}$ \\
\hline T200 & 560.0 & 18.5 & $3.58 \pm 0.05$ \\
T300 & 200.0 & 26.4 & $3.89 \pm 0.06$ \\
T400 & 188.7 & 30.8 & $4.17 \pm 0.02$ \\
T500 & 235.4 & 21.6 & $4.19 \pm 0.05$ \\
T700 & 247.9 & 19.7 & $4.21 \pm 0.09$ \\
T800 & 254.2 & 18.9 & $4.22 \pm 0.01$ \\
\hline
\end{tabular}
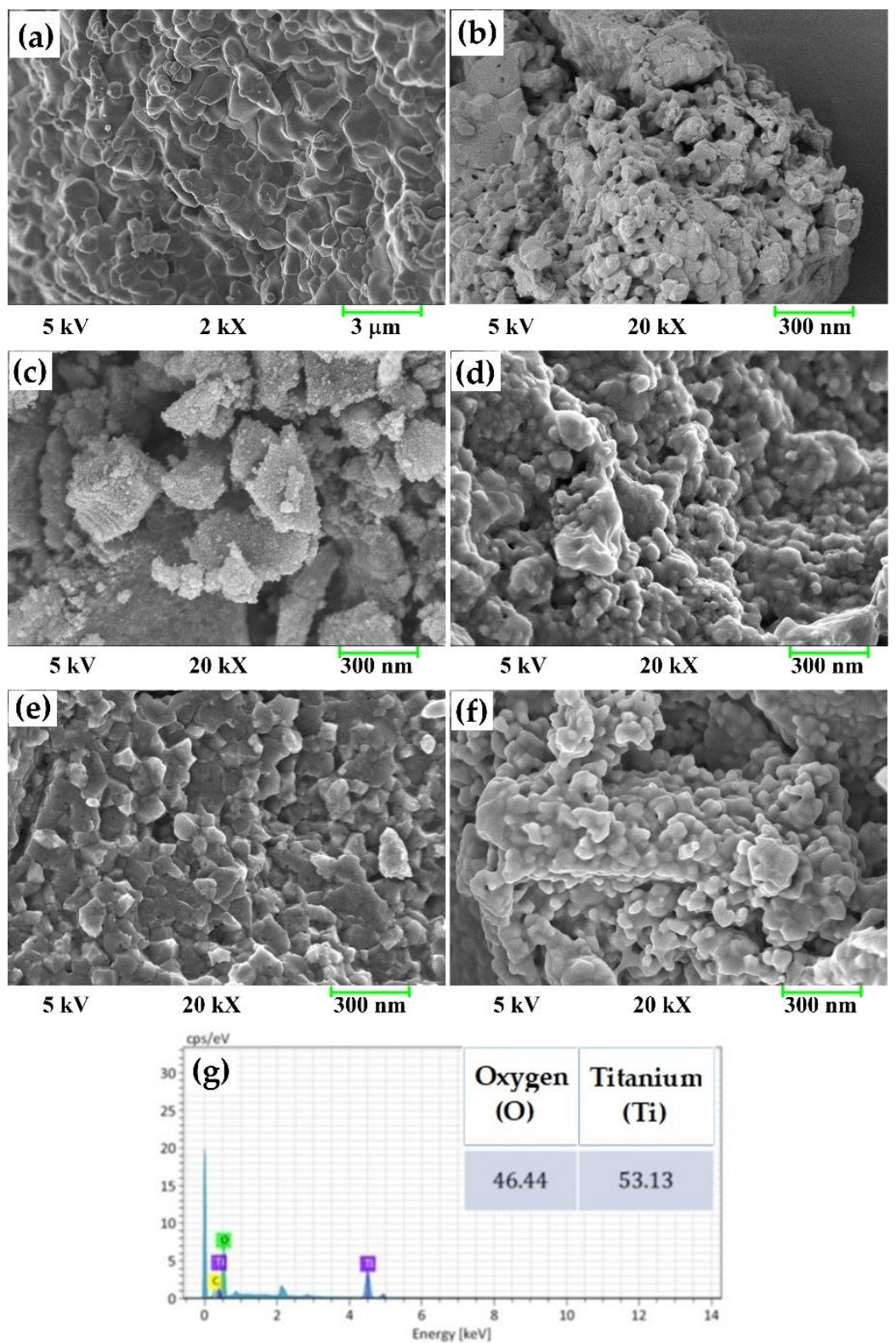

Figure 2. SEM images taken from the synthesized $\mathrm{TiO}_{2}$ submicron powders: a) T200, (b) T300, (c) $\mathrm{T} 400$, (d) T500, (e) T700, (f) T800 and (g) T300-EDS.

Table 1 summarizes the physical properties of the powders. The theoretical density of $\mathrm{TiO}_{2}$ is 4.23 $\mathrm{g} / \mathrm{cm}^{3}$. The particle sizes of $\mathrm{TiO}_{2}$ submicron powders synthesized at different temperatures were between 
the range of $200-510 \mathrm{~nm}$, while the specific surface areas (BET) of them are $18.5-30.8 \mathrm{~m}^{2} / \mathrm{g}$. Particle size distributions (PSDs) of $\mathrm{TiO}_{2}$ submicron powders were shown in Figure 3. T200 sample had an average size of $560 \mathrm{~nm}$ (Figure 3a). Otherwise, T400 and T800 samples displayed a unimodal PSD. During the phase transformation from anatase to rutile, while the particle size of the powders decreased, the particle size of the powders increased in proportion to the calcination temperature in rutile form. It is clear that the anatase to rutile phase transformation caused a degradation in the particle sizes of synthesized powders. In addition, the rate of this transformation enhanced with increasing calcination temperature in the rutile form of $\mathrm{TiO}_{2}$. Moreover, the particle sizes of calcinated powders were increased which is supported by the BET results regarding their surface area decreasing from 30.08 to $18.9 \mathrm{~m}^{2} / \mathrm{g}$. Compare to previous studies, $\mathrm{TiO}_{2}$ submicron powders are obtained at lower temperature (Chen et al., 2003; Li et al., 2008; CanoCasanova et al., 2018). The pycnometer density of the synthesized $\mathrm{TiO}_{2}$ submicron powders was given in Table 1. When $\mathrm{TiO}_{2}$ submicron powders were synthesized by at $400{ }^{\circ} \mathrm{C}$, pycnometer density values increased. And also, they have gotten closer to theoretical density, which is $4.23 \mathrm{~g} / \mathrm{cm}^{3}$.

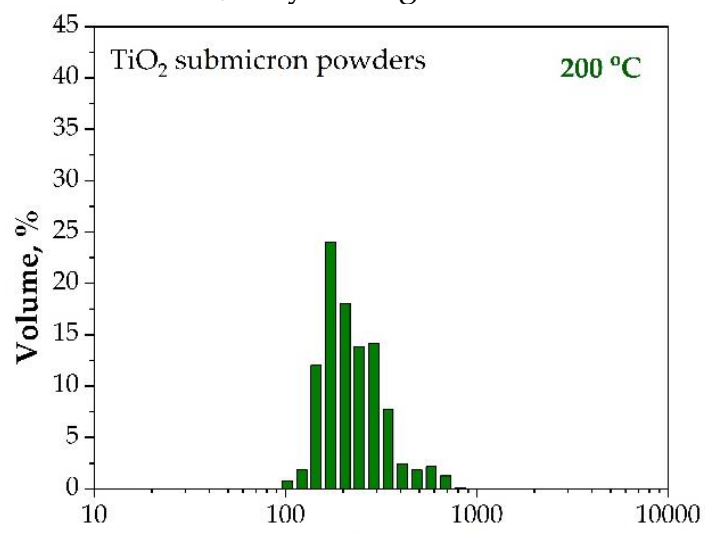

(a)

Particle Size, nm

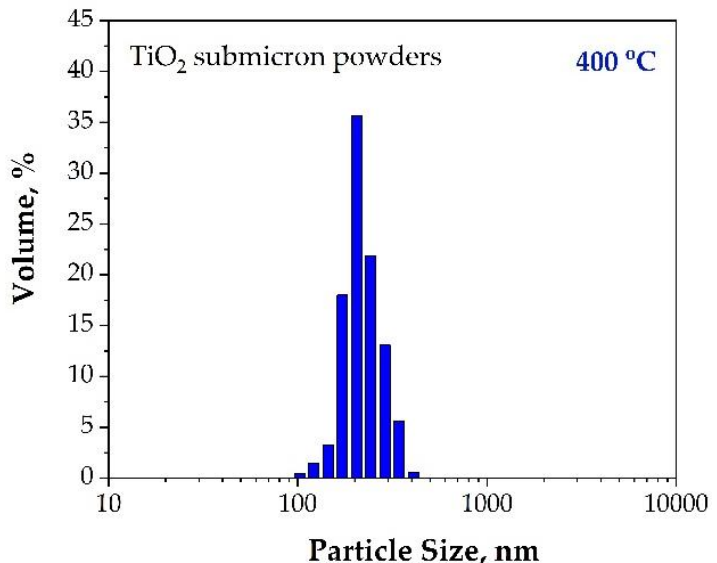

(c)

Particle Size, $\mathbf{n m}$

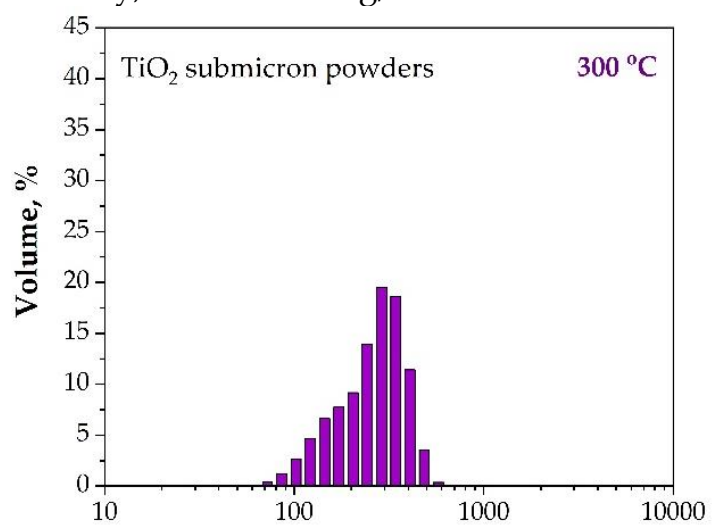

(b)

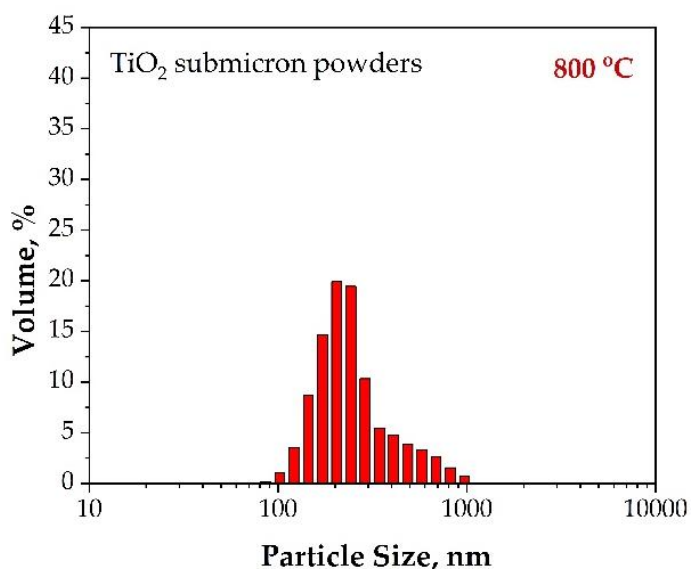

Figure 3. Particle size distributions of $\mathrm{TiO}_{2}$ submicron powders: (a) $200^{\circ} \mathrm{C}$, (b) $300^{\circ} \mathrm{C}$, (c) $400{ }^{\circ} \mathrm{C}$, and (d) $800^{\circ} \mathrm{C}$.

Figure 4. shows the XRD patterns of calcinated submicron powders at different temperatures in the range of $200-800{ }^{\circ} \mathrm{C}$. As seen in the XRD patterns in Figure 4a, the dominant peaks of anatase were detected at $2 \theta$ values of $25.3^{\circ}(101), 54.5^{\circ}(105), 48.0^{\circ}(200), 37.8^{\circ}(004), 55.0^{\circ}(211), 62.7^{\circ}(204), 68.9^{\circ}(116)$, and $70.3^{\circ}(220)$, while the peaks located at $25.7^{\circ}(111), 25.3^{\circ}(120)$ and $30.8^{\circ}(121)$ corresponded to brookite in accordance with Powder Diffraction Standard (JCPDS card no. 00-064-0863) (Li et al., 2008; CanoCasanova et al., 2018). The anatase form of $\mathrm{TiO}_{2}$ has a tetragonal structure, whereas the brookite phase is an orthorhombic structure. The patterns of $\mathrm{TiO}_{2}$ submicron powders synthesized in the range of 400-800 ${ }^{\circ} \mathrm{C}$ only show the existence of pure $\mathrm{TiO}_{2}$ with a rutile-crystal structure, which is compatible with the standard data from the JCPDS PDF card 01-086-0148. The rutile $\mathrm{TiO}_{2}$ phase is also a tetragonal structure comprising of the characteristic peaks at $2 \theta=27.4^{\circ}, 36.1^{\circ}, 41.2^{\circ}, 54.3^{\circ}, 56.6^{\circ}$ and $69.0^{\circ}$ corresponding to 
(110), (101), (111), (211), (220) and (301) planes, respectively. The anatase phase of $\mathrm{TiO}_{2}$ started to form at the calcination temperature of $200{ }^{\circ} \mathrm{C}$. The transformation of anatase to rutile phase was completed after calcination at $400{ }^{\circ} \mathrm{C}$, and an additional phase was not observed. It was observed that XRD peaks were sharper and narrower when the calcination temperature of $\mathrm{TiO}_{2}$ was increased. In addition, the increased crystallinity of $\mathrm{TiO}_{2}$ was associated with increasing the calcination temperature to $400{ }^{\circ} \mathrm{C}$ and above. This result is lower than that reported by Chen et al. (2003) at $250{ }^{\circ} \mathrm{C}$ and $600{ }^{\circ} \mathrm{C}$, respectively. It is seen in Figure $4 \mathrm{c}$, the calcination temperatures play a significant role in the change of the crystalline phase. Our findings have coherency with the results of a study reported by Phromma et al. (2020). An important result of their study was proving that the necessity of a high calcination temperature in the transformation process of anatase into the rutile phase. Although many studies have been published about hydrothermally synthesized $\mathrm{TiO}_{2}$, it has not been reported to the occurrence of the anatase formation at a low temperature as $200{ }^{\circ} \mathrm{C}$, and also the anatase phase transform to the rutile at $400{ }^{\circ} \mathrm{C}$. Although many studies have been published about hydrothermally synthesized $\mathrm{TiO}_{2}$, it has not been previously reported to the occurrence of the anatase formation at a low temperature as $200{ }^{\circ} \mathrm{C}$, and also the anatase phase transform to the rutile at $400{ }^{\circ} \mathrm{C}$. By this aspect, the synthesis of the pure $\mathrm{TiO}_{2}$ phase at lower temperature is an original study.
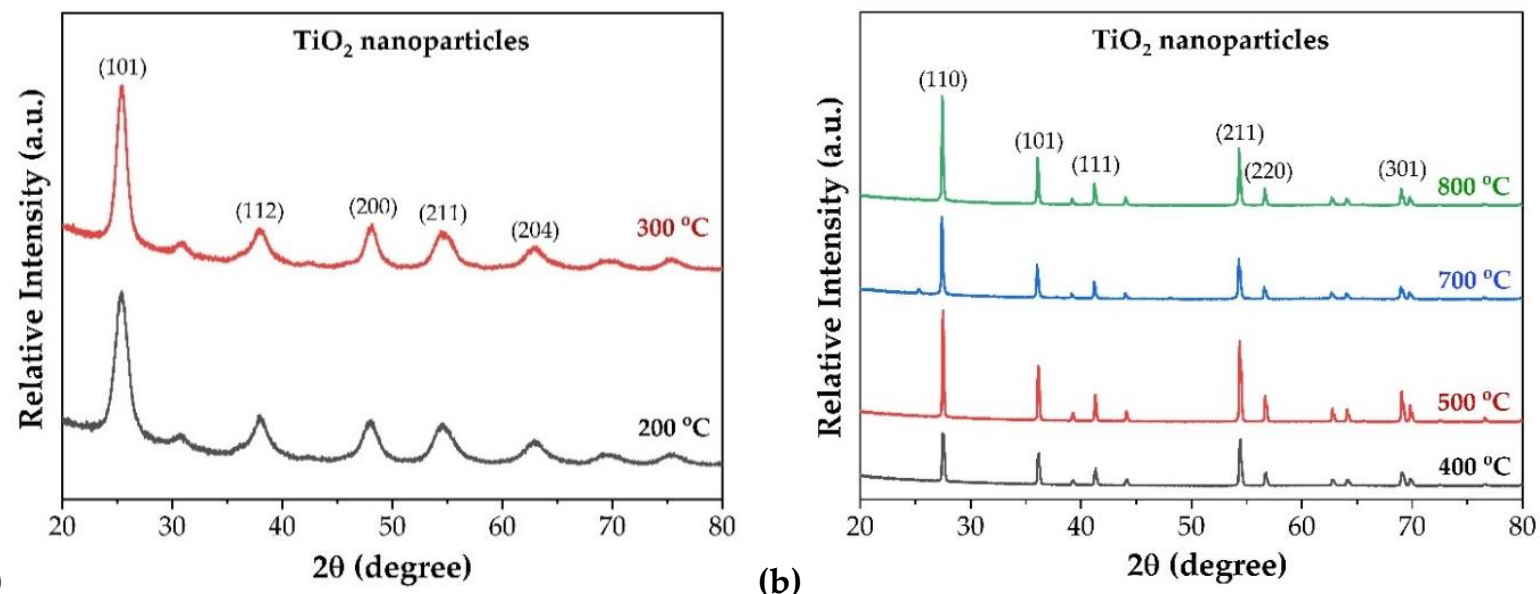

(a)

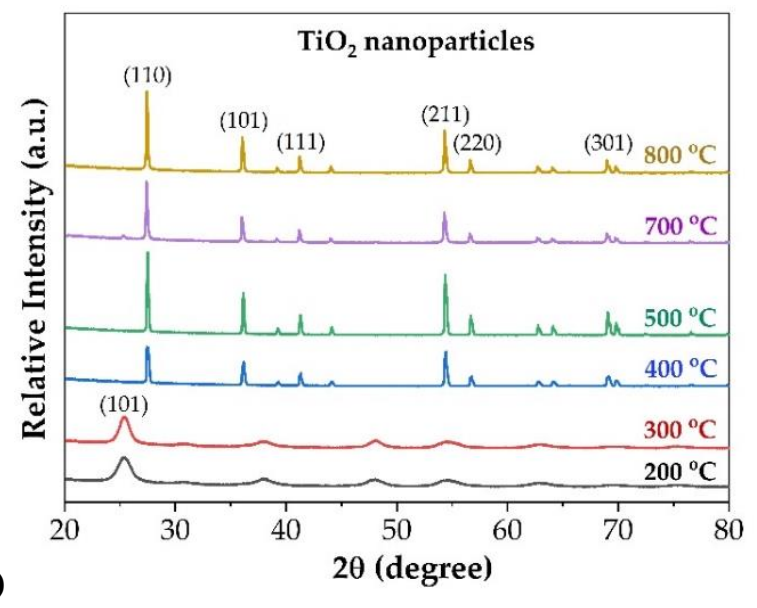

Figure 4. XRD patterns of the synthesized submicron powders: (a) $\mathrm{TiO}_{2}$ in anatase phase, (b) $\mathrm{TiO}_{2}$ in rutile phase, and (c) $\mathrm{TiO}_{2}$ submicron powders (taken collectively).

The average crystallite sizes (D) of $\mathrm{TiO}_{2}$ submicron powders were determined using the full width at half maximum (FWHM) of their XRD peaks according to Debye-Scherrer's equation (Duman et al. 2020; Venkateswarlu et al. 2010; Cheong et al. 2013): 


$$
D=\frac{K \lambda}{\beta \cos \theta}
$$

where $\beta$ is the corrected half-peak width of the experimental sample (FWHM), $\theta$ is Bragg angle, $\lambda$ is the $\mathrm{X}$-ray wavelength $(0.15406 \mathrm{~nm}$ for $\mathrm{CuK} \alpha$ radiation), and $\mathrm{K}$ is the shape factor (approximately equal to $0.89)$.

XRD results of the $\mathrm{TiO}_{2}$ submicron powders were given in Table 2. The XRD patterns of $\mathrm{TiO}_{2}$ submicron powders synthesized at 200 and $300{ }^{\circ} \mathrm{C}$ changed in comparison $\mathrm{TiO}_{2}$ submicron powders synthesized at higher calcination temperatures. In Table 2, the mean crystalline size of the $\mathrm{TiO} 2$ submicron powders is in the range of $16.8-60.7 \mathrm{~nm}$. Furthermore, the crystallite sizes of all phases increased at temperatures ranging from $200{ }^{\circ} \mathrm{C}$ to $800{ }^{\circ} \mathrm{C}$ as presented in Table 2 . Table 2 indicated the improvement in the crystallization of $\mathrm{TiO}_{2}$ submicron powders. This study revealed that calcination temperature affected phase transformation, crystallite size, and crystallinity of $\mathrm{TiO}_{2}$ submicron powders. The crystallite size and particle size of a single-crystal nanoparticle are the same (Nalwa, 2000). Synthesized $\mathrm{TiO}_{2}$ submicron powders have polycrystalline or single crystalline structures depending on synthesis process conditions. Therefore, particle size values of $\mathrm{TiO}_{2}$ submicron powders are corresponding a different inference than crystallite size values.

Table 2. XRD results of $\mathrm{TiO}_{2}$ submicron powders.

\begin{tabular}{c|cccc}
\hline \multirow{2}{*}{ Temperature $\left({ }^{\circ} \mathbf{C}\right)$} & $\mathbf{2 \theta}\left({ }^{\circ} \mathbf{C}\right)$ & $\mathbf{D}(\mathbf{n m})$ & \multicolumn{2}{c}{ Lattice parameters } \\
\hline 200 & $25.3(101)$ & 16.8 & 0.3785 & 0.9494 \\
300 & $25.3(101)$ & 17.4 & 0.3785 & 0.9494 \\
400 & $27.4(110)$ & 30.8 & 0.3251 & 0.5209 \\
500 & $27.4(110)$ & 49.3 & 0.3252 & 0.5209 \\
700 & $27.4(110)$ & 60.7 & 0.4594 & 0.2959 \\
800 & $27.4(110)$ & 54.9 & 0.4592 & 0.2957 \\
\hline
\end{tabular}

The percentage of crystallinity (Xc\%) was predicted using the equation below (Tatar et al. 2016):

$$
X c \%=\frac{\Sigma A c}{\Sigma A c+\Sigma A a} \times 100
$$

$\Sigma A c$ is the total area under crystal peaks, and $\Sigma A a$ is the total area under amorphous peaks.

The crystallinity results given in Figure 5 indicated that $\mathrm{TiO}_{2}$ submicron powders calcinated at $200^{\circ} \mathrm{C}$ involve crystalline phase content (78\%) with respect to amorphous phase content (22\%). More increase of temperature (from 200 to $800^{\circ} \mathrm{C}$ ) in the calcination method demonstrates the decrease in the amount of amorphous phase $(6 \%)$ and increase in the amount of crystalline phase $(94 \%)$ in the $\mathrm{TiO}_{2}$ submicron powders. Hence, it may be interpreted as the increase in the crystal phase rate of $\mathrm{TiO}_{2}$ submicron powders is strongly related to the calcination temperature. 


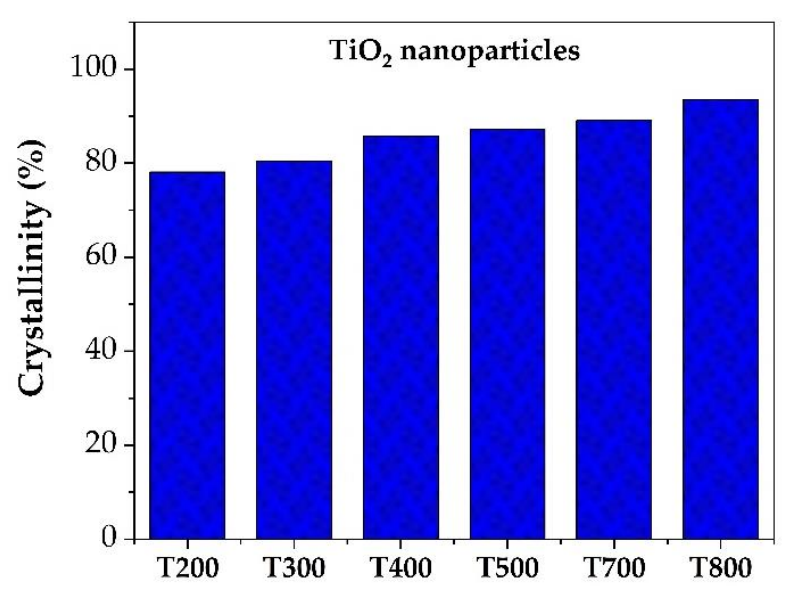

Figure 5. The calculated values of the phase crystallinity $\mathrm{TiO}_{2}$ submicron powders.

Consequently, the hydrothermal and calcination dual methods provided the synthesis of pure $\mathrm{TiO}_{2}$ submicron powders. The calcination temperature has a significant effect on the crystalline phases and crystallinities of synthesized submicron powders. The utilized process could be a promising novel material synthesis method for submicron-scale materials.

\section{CONCLUSIONS}

In this study, $\mathrm{TiO}_{2}$ submicron powders were successfully produced by the combination of hydrothermal synthesis and calcination. The effects of calcination temperatures ranging from $200{ }^{\circ} \mathrm{C}$ to $800{ }^{\circ} \mathrm{C}$ were detailly investigated. According to the obtained results, the following conclusions can be summarized as:

1. Morphological characterizations revealed that $\mathrm{TiO}_{2}$ submicron powders have irregularly shaped clusters. Besides, the changing calcination temperatures affected the crystalline structure of the powders.

2. The particle size values of the $\mathrm{TiO}_{2}$ submicron powders synthesized at different temperatures were between the range of $200-510 \mathrm{~nm}$, while the specific surface area (BET) values were between $18.5-30.8$ $\mathrm{m}^{2} / \mathrm{g}$.

3. According to phase analysis results, anatase and rutile $\mathrm{TiO}_{2}$ submicron powders were synthesized at low temperatures. Furthermore, the crystallite size of the analyzed samples increased with heightening calcination temperatures.

\section{ACKNOWLEDGEMENTS}

This work was supported financially by Bursa Technical University Scientific Research Projects (project no. 190Y017). The authors thank Bursa Technical University Central Research Laboratory for providing laboratory facilities for this research.

\section{REFERENCES}

Andersson, M., Österlund, L., Ljungstroem, S., Palmqvist, A., 2002, “Preparation of nanosize anatase and rutile $\mathrm{TiO}_{2}$ by hydrothermal treatment of microemulsions and their activity for photocatalytic wet oxidation of phenol", The Journal of Physical Chemistry B, 106(41), p. 10674-10679.

Ayllon, J., Figueras, A., Garelik, S., Spirkova, L., Durand, J., Cot, L., 1999, “Preparation of $\mathrm{TiO}_{2}$ powder using titanium tetraisopropoxide decomposition in a plasma enhanced chemical vapor deposition (PECVD) reactor", Journal of Materials Science Letters, 1999. 18(16): p. 1319-1321.

Benkstein, K.D., Semancik, S., 2006, "Mesoporous nanoparticle $\mathrm{TiO}_{2}$ thin films for conductometric gas sensing on microhotplate platforms", Sensors and Actuators B: Chemical, 113(1): p. 445-453. 
Chae, S. Y., Park, M. K., Lee, S. K., Kim, T. Y., Kim, S. K., Lee, W. I., 2003, “Preparation of size controlled $\mathrm{TiO}_{2}$ nanoparticles and derivation of optically transparent photocatalytic films", Chemistry of Materials, 15(17), ): p. 445-453.

Chen, Y.-F., Lee, C. Y., Yeng, M. Y., \& Chiu, H. T., 2003, "The effect of calcination temperature on the crystallinity of $\mathrm{TiO}_{2}$ nanopowders", Journal of Crystal Growth, 247(3-4): p. 363-370.

Chen, X., Mao, S.S., 2007, “Titanium dioxide nanomaterials: synthesis, properties, modifications, and applications", Chemical reviews, 107(7): p. 2891-2959.

Cheong, Y.L., Yam, F.K., Chin, I.K., Hassan, Z., 2013, “X-ray analysis of nanoporous $\mathrm{TiO}_{2}$ synthesized by electrochemical anodization", Superlattices Microstruct., 64: p. 34-43.

Corradi, A.B., Bondioli, F., Focher, B., Ferrari, A. M., Grippo, C., Mariani, E., \& Villa, C., 2005, "Conventional and microwave-hydrothermal synthesis of $\mathrm{TiO}_{2}$ nanopowders", Journal of the American Ceramic Society, 88(9): p. 2639-2641.

Ding, K., Miao, Z., Hu, B., An, G., Sun, Z., Han, B., \& Liu, Z., 2010, “Study on the Anatase to Rutile Phase Transformation and Controlled Synthesis of Rutile Nanocrystals with the Assistance of Ionic Liquid“, Langmuir, 2010. 26(12): p. 10294-10302.

Duman, Ş., Bulut, B., Ozkal, B., 2020, "Antibacterial and Optical Properties of Mn Doped ZnO Nanopowders Synthesized via Spray Drying and Subsequent Thermal Decomposition", Çukurova University Journal of the Faculty of Engineering and Architecture, 35(4), p. 1073-1081.

Feng, P., Gao, C., Shuai, C., Peng, S., 2015, "Toughening and strengthening mechanisms of porous akermanite scaffolds reinforced with nano-titania“, RSC advances, 5(5), p. 3498-3507.

Hashimoto, K., Irie H., Fujishima, A., 2005, “ $\mathrm{TiO}_{2}$ photocatalysis: a historical overview and future prospects", Japanese Journal of Applied Physics, 44(12R): p. 8269.

Hird, M., 1976, "Transmission of ultraviolet light by films containing titanium pigments - applications in uv curing", Pigment \& Resin Technology.

Li, H., Duan, X., Liu, G., Jia, X., Liu, X., 2008, “Morphology controllable synthesis of $\mathrm{TiO}_{2}$ by facile hydrothermal process", Materials Letters, 62(24): p. 4035-4037.

Manjunath, K., Yadav, L. S. R., Jayalakshmi, T., Reddy, V., Rajanaika, H., Nagaraju, G., 2018, Ionic liquid assisted hydrothermal synthesis of $\mathrm{TiO}_{2}$ nanoparticles: photocatalytic and antibacterial activity. Journal of Materials Research and Technology, 7(1): p. 7-13.

McCormick, J.R., J. R., Zhao, B., Rykov, S. A., Wang, H., \& Chen, J. G., 2004. “Thermal stability of flamesynthesized anatase $\mathrm{TiO}_{2}$ nanoparticles", The Journal of Physical Chemistry B, 108(45): p. 1739817402.

Mioduska, J., Zielińska-Jurek, A., Janczarek, M., \& Hupka, J., 2016. “The Effect of Calcination Temperature on Structure and Photocatalytic Properties of $\mathrm{WO}_{3} / \mathrm{TiO}_{2}$ Nanocomposites" Journal of Nanomaterials, vol. 2016, Article ID 3145912, 8 pages. https://doi.org/10.1155/2016/3145912

Nalwa, H.S., 2000, Handbook of nanostructrured Materials and Nanotechnology ,Vol 2: Spectroscopy and Theory", Academic Press, p. 155-167.

Pelizzetti, E., C. Minero, 1993, "Mechanism of the photo-oxidative degradation of organic pollutants over $\mathrm{TiO}_{2}$ particles", Electrochimica acta, 38(1): p. 47-55.

Phromma, S., T. Wutikhun, P. Kasamechonchung, T. Eksangsri, C. Sapcharoenkun, 2020. “Effect of

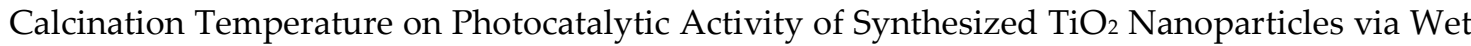
Ball Milling Sol-Gel Method “, Applied Science, 10(3): p. 993-1006.

Rao, N.N., S. Dube, 1996, "Photocatalytic degradation of mixed surfactants and some commercial soap/detergent products using suspended $\mathrm{TiO}_{2}$ catalysts", Journal of Molecular Catalysis A: Chemical, 104(3): p. L197-L199.

Tan, Z., K. Sato, S. Ohara, 2015, "Synthesis of layered nanostructured $\mathrm{TiO}_{2}$ by hydrothermal method", Advanced Powder Technology, 26(1): p. 296-302.

Tatar, C., Bagci, D., Kaygili, O., 2016, "The effects of high amounts of Al and Zn on the structural properties of hydroxyapatite prepared by sol-gel method", J. Ceram. Process. Res., 17: p. 426-429 
Tomić, N., Grujić-Brojčin, M., Finčur, N., Abramović, B., Simović, B., Krstić, J., Šćepanović, M., 2015, "Photocatalytic degradation of alprazolam in water suspension of brookite type $\mathrm{TiO}_{2}$ nanopowders prepared using hydrothermal route", Materials Chemistry and Physics, 163, p. 518-528.

Venkateswarlu, K., Chandra Bose, A., Rameshbabu, N., 2010, "X-ray peak broadening studies of nanocrystalline hydroxyapatite by Williamson-Hall analysis", Phys. B, 405: p. 4256-4261.

Yang, J., Mei, S., Ferreira J., 2001, "Hydrothermal synthesis of $\mathrm{TiO}_{2}$ nanopowders from tetraalkylammonium hydroxide peptized sols", Materials Science and Engineering: C, 15(1-2): p. 183-185.

Zheng, L., $\mathrm{Xu}, \mathrm{M} ., \mathrm{Xu}, \mathrm{T} ., 2000$, " $\mathrm{TiO}_{2}-\mathrm{x}$ thin films as oxygen sensor", Sensors and Actuators B: Chemical, 66(1-3): p. 28-30.

Wu, H., Fan, J., Liu, E., Hu, X., Ma, Y., Fan, X., Tang, C., 2015, “Facile hydrothermal synthesis of TiOz nanospindles-reduced graphene oxide composite with a enhanced photocatalytic activity“ Journal of Alloys and Compounds, 623: p. 298-303. 